Portland State University

PDXScholar

\title{
A Multi-institutional Model for Advancing Open Access Journals and Reclaiming Control of the Scholarly Record
}

Christopher V. Hollister

University at Buffalo, cvh2@buffalo.edu

Karen Bjork

Portland State University, kbjork@pdx.edu

Stewart Brower

University of Oklahoma -Tulsa, stewart-brower@ouhsc.edu

Follow this and additional works at: https://pdxscholar.library.pdx.edu/ulib_fac

Part of the Scholarly Communication Commons, and the Scholarly Publishing Commons Let us know how access to this document benefits you.

\section{Citation Details}

Hollister, Christopher V.; Bjork, Karen; and Brower, Stewart, "A Multi-institutional Model for Advancing Open Access Journals and Reclaiming Control of the Scholarly Record" (2021). Library Faculty Publications and Presentations. 322.

https://pdxscholar.library.pdx.edu/ulib_fac/322

This Post-Print is brought to you for free and open access. It has been accepted for inclusion in Library Faculty Publications and Presentations by an authorized administrator of PDXScholar. Please contact us if we can make this document more accessible: pdxscholar@pdx.edu. 


\author{
A Multi-institutional Model for Advancing Open Access Journals and Reclaiming Control \\ of the Scholarly Record \\ Christopher Hollister \\ Presenter \\ Karen Bjork \\ Presenter \\ Stewart Brower \\ Presenter
}

The open access journal Communications in Information Literacy (CIL) began publication in 2007. After ten years of continuous growth, CIL migrated from Online Journals Systems (OJS) and a commercial web host to Portland State's Digital Commons (bepress) publishing platform, $P D X S$ cholar. The presenters provide brief overviews of CIL and PDXScholar, and they detail the challenges and ultimate successes of this multi-institutional model for advancing open access journals and reclaiming control of the scholarly record. They highlight the content migration process from OJS to $P D X S$ cholar, post-migration actions to correct metadata, the introduction of functioning DOIs, and coordinating with both free web and commercial indexers to ensure proper access to the newly moved journal. The presenters also discuss the practicalities and the policy implications of this move, particularly in light of Elsevier's acquisition of bepress. Finally, the presenters advance their partnership as an exemplar of transformational publishing and as a viable, sustainable model for scholars in other fields to emulate.

KEYWORDS open access journals, open access publishing, journal publishing platforms BODY OF PAPER

\title{
Introduction and Brief Hisotry
}


This is a case study about an independent, library-published journal, its origins, its growth, and its shift from one model and platform to another. For those who are in the scholarly communication business, this is also a success story about sustainable open access publishing, regaining a measure of control over the field's scholarly record, and choosing the right strategic partners for doing so.

The journal Communications in Information Literacy (CIL) is an independently published, peer-reviewed, and open access journal. It is open access in the purest sense (i.e., no author processing charges). CIL publishes research, theory, and practice in the area of information literacy in higher education. The journal launched in 2007. It is presently in volume year number 14, and its reach and visibility is well established in terms of both free web and commercial directories, indices, and archives.

The co-founders and co-editors, Stewart Brower and Christopher Hollister, commenced with developing CIL over a year before its launch in 2007. (For those who may have similar publishing ambitions, that amount of time and effort is highly recommended to increase the likelihood of a successful launch and run.) At the time, there were no scholarly journals devoted to information literacy. Research Strategies had ceased publication, and though other journals were publishing papers on information literacy, none were focused solely on that topic. The editors were frustrated by many of their publishing experiences at the time; they believed there were better ways of operating scholarly serials. In addition, they recognized what were then the emergent possibilities of open access publishing and potentially regaining some disciplinary control over the literature on information literacy.

CIL was developed as a values-driven journal. To begin, the co-editors are fervent and longtime advocates for advancing information literacy. They value their editorial independence 
from commercial publishers, universities, and professional societies, and they abide by the library field's core principle: free to all. They endeavor to advance the ideals of professional mentorship, inclusion, and even environmental stewardship. In addition, they attribute great value to operating with professionalism, courtesy, and decency.

The topic of open access journal publishing commonly generates questions about economic models and sustainability. CIL's financial requirements have always been modest; its expenses were mainly for web hosting fees on its original platform. For the first few years, the journal operated on the PBS model: plead, beg, and steal! The co-editors even experimented with print-on-demand issues of the journal to generate funds. After a few years, however, the quality of the product started to pay dividends, and CIL began to build a modest treasury thanks to vendor royalties.

Measures of CIL's success are realized in a variety of ways. In 2009, the editors were awarded the Association of College and Research Libraries Instruction Section's Special Certificate of Recognition and Appreciation. Notwithstanding the limitations of impact metrics, the co-editors also like to tout CIL's current SCImago Journal Rank, which places CIL at number fourteen among 248 journals in the library field. The editors believe it is fair to say that it would have been difficult to imagine that an independent, library-published, open access journal experiment could achieve this standing when CIL was first launched.

CIL was originally developed under the umbrella of the University at Buffalo Libraries on the Online Journals Systems (OJS) platform, which worked well for several years. In 2017, for a variety of reasons - mainly practical in nature - the journal moved to Portland State University (PSU) and its celebrated Digital Commons platform, PDXScholar. One of the leading reasons for the move was the co-editors' lack of capacity to manage the growth of CIL under its 
original publishing model. It is important to note here, for those who may have preconceived notions about Digital Commons, that the move to PDXScholar preceded Elsevier's acquisition of bepress. Accordingly, CIL's publishing agreement is with PSU, not Elsevier. Furthermore, the editors wish to state for the record that their colleagues at PSU and bepress have been excellent partners in this enterprise.

\section{PDXScholar}

Like many library publishing programs, PSU Library's program grew out of its institutional repository services. Having gained experience disseminating faculty post-prints and other original scholarly content, the Library was seeking opportunities to expand into the realm of publishing scholarly journals.

In July 2013, the Library migrated its institutional repository, PDXScholar, from Dspace to Digital Commons. The migration provided the Library with the capability to develop an ejournal publishing program. To begin that process, the PDXScholar team reached out to the editors of established print journals. This helped them to think strategically about potential publishing services they could provide, services the Library would like to provide, and the level of staffing needed to support their editors. Accordingly, PDXScholar developed services that included consultation on editorial workflow management, software configuration, graphic design, initial training, backfile uploading, intellectual property rights and copyright support, preservation, digital review of all new published issues for metadata quality, and ongoing systems support. The Library also provided ISSN registration and assigned digital object identifiers (DOIs). By 2016, the PDXScholar team was supporting and publishing three PSU student journals. 


\section{CIL Migration}

In early 2016, the Library was approached by a PSU-affiliated CIL editor regarding the possibility of the journal migrating to PDXScholar. The PDXScholar team spent the first few months getting to know the CIL editors and their journal. Until it was approached by CIL, the Library's policy was to host only PSU faculty-edited journals; the notion of offering hosting services to unaffiliated editors had not been explored. The PDXScholar team also needed to verify that the CIL editors were comfortable with having their journal connected to PSU after the affiliated editor retired from the editorial team. During the nine month period from June 2016 to March 2017, the Library updated its publishing policies and editor agreement (see Appendix I). In March 2017, CIL officially became part of the Library’s journal publishing program.

The PDXScholar team assumed the responsibility of migrating CIL and its backfiles. The migration of volumes 1-10 (197 articles) started in March 2017, and it was completed in December of that year. During the migration period, the PDXScholar team worked with the CIL editors to finalize the new journal site and to train them on the new platform.

\section{Process}

Migration is a complex process. The steps listed in Appendix II provide a snapshot of what was required to migrate CIL from the OJS platform to PSU's version of Digital Commons. The general procedure involved the use of XML to retrieve the journal's metadata, the PDF versions of published works, the roster of manuscript reviewers, and CIL's information pages (i.e., About This Journal, Aims and Scope, Editorial Board, Policies, Author Guidelines, Publication Ethics, etc.). The migration process also provided the opportunity to conduct critical metadata mapping and clean-up. 


\section{Communication}

This was a new kind of partnership for the Library and for CIL. It was necessary for the editors to have trust in their new partner's ability to successfully migrate and host their journal, and it was incumbent of the PDXScholar team to reinforce that trust by delivering what had been promised. Accordingly, the Library established a point person to clearly communicate expectations, noting in particular what the Digital Commons platform can and cannot do.

The migration process required a temporary suspension of some of CIL's operations. The editors communicated to contributing authors and to the broader information literacy community that it was not accepting new submissions until the migration was completed. Peer review and editorial processes for previously submitted manuscripts were carried out on the OJS version of the journal, which was maintained for the transition period and for the following calendar year. The editors revised the landing page on the OJS version of the journal, directing readers and potential contributors to the new site on PDXScholar. In addition, one of the editors reached out to the Digital Commons community and received support from several institutions that had already gone through the process of migrating from the OJS platform.

\section{Metadata Corrections}

Although the migration of CIL from OJS to PDXScholar was thorough, some corrections to the metadata were still necessary. The editors noted a significant issue with author names shortly after the migration. While bepress maintains a central registry of authors, the OJS system applies author names only at the article level. Additionally, author names in OJS include a field for a middle initial or a middle name. However, many of the articles migrated to PDXScholar without the contents of that field. To correct this, one of the CIL editors assigned a graduate research assistant to review each article in both the OJS and Digital Commons systems, identify 
where middle names or initials were missing, log the discrepancy, and manually edit the PDXScholar article records directly. Roughly 100 articles were affected.

\section{Download Counts}

Download figures represented another metadata discrepancy. This is an important metric, which CIL authors commonly cite in their annual reports, and in their promotion and tenure dossiers. In the OJS system, download counts were not publicly viewable, so authors routinely contacted the editors to request those statistics. The move to PDXScholar made downloads visible to all readers; however, there was no reasonable way for OJS figures to serve as the starting points on the new platform. For the sake of accuracy, OJS and PDXScholar downloads needed to be considered and displayed separately, and then added together.

Although PDXScholar records include a field labeled "Downloads prior to this publication," the migration from OJS did not capture that data. Once again, the editors assigned a graduate assistant to manually enter those numbers into the records for each migrated article. A coordinated effort between the PDXScholar team and bepress made the field visible to readers, who can now see "Downloads prior to this publication" for all records prior to the migration, as well as a new count for downloads since the migration. As illustrated in Figure 1, any article will show a number indicating "Downloads since" followed by a date of publication. For migrated articles, this is the "go live" date of CIL on PDXScholar. In addition, articles originally published on the OJS version of CIL will also show "Downloads prior to this publication."

Figure 1 Example of download counts (see below)

\section{Digital Object Identifiers and Indexing}

The PSU Library is a CrossRef member, and therefore, its publishing services include assigning DOIs to all journal articles that it publishes. As the PDXScholar team and CIL's 
editors discussed the migration process and the future of journal, it became evident that retaining DOIs already assigned to articles published in OJS was a priority. As the PDXScholar team investigated options, they realized that while DOIs had been added to the articles published in OJS, those identifiers were not registered. The conversation shifted to working out an agreement in which the PDXScholar team would assign DOIs to all (past and current) articles published in CIL, embed itself in the production workflow, and perform certain DOI-related responsibilities. The Library also agreed to pay the fees incurred by new DOIs. Once the new DOIs were established, it was necessary to re-index the corresponding titles in the Directory of Open Access Journals (DOAJ). In the short term, new DOAJ metadata was created from the XML output of the old OJS system, but this required that all new issues of the journal be entered into DOAJ by hand. Last year, the PDXScholar team developed a tool that allows it to import and update data in DOAJ automatically once a new issue is published, saving time and eliminating inevitable data entry errors.

\section{Conclusion}

Undertaking the migration of any journal from one platform to another is a daunting prospect. The work is highly detailed, and it requires considerable effort to account for elements that automated processes might miss. Even migrating a small backfile of issues and articles to a new platform requires exceptional technical capacity and expertise. The editors of CIL were fortunate to find a willing partner in the PSU Library, which possesses these remarkable qualities.

The actual migration of a journal is only one part of the story. The open access publishing movement has catered to those with an entrepreneurial spirit, but the number of failed titles is staggering. Entrepreneurial spirit is not enough. Free software and affordable web hosts are 
likewise not enough. Partnerships between scholarly journals and library publishers can introduce greater stability in open access publishing and has the potential to facilitate new and sustainable growth. The presenters of this paper assert that it is not necessary for editors or publishers operate in isolation in the open access world. Strength is found through partnership.

\section{CONTRIBUTOR NOTES}

Christopher Hollister is the Head of Scholarly Communication for the University at Buffalo Libraries.

Karen Bjork is the Head of Digital Initiatives and Scholarly Publishing at Portland State University.

Stewart Brower is the Library Director at the University of Oklahoma - Tulsa. 


\section{APPENDIX I}

\section{Memorandum of Understanding (MOU)}

\section{PDXScholar E-Journal Hosting}

1. Portland State University Library wishes to become more involved in the promotion of scholarly communications and to support open access publishing initiatives by making available an online-hosting service for Portland State University-associated academic electronic Journals.

2. (the "Publisher") publishes the e-journal (the "e-journal").

The parties agree as follows:

(a) Portland State University Library will:

(i) Make the contents of the e-journal available free of charge to the University community and the public via the Internet or any subsequent technology;

(ii) Provide access to PDXScholar;

(iii) Provide the Publisher with free hosting services;

(iv) Provide free and open access to the contents of the "e-journal" for so long as the resource is hosted on PDXScholar; and

(v) In the event of a decision to discontinue hosting services provide the Publisher with 6 months prior written notice of its intention to do so.

(b) The Publisher will:

(i) Be fully responsible for all aspects of the creation and updating of "e- journal" content to PDXScholar; 
(ii) Acknowledge that Portland State University is providing these services as an accommodation to the Publisher and the Portland State University Library shall not be liable for any damages, costs or losses whatsoever arising in any circumstances from these services including, without limitation, damages arising from the breakdown of the technology, the failure to install upgrades and difficulties with access.

(iii) Be fully responsible for the content of the e-journal and indemnify and hold harmless Portland State University Library from any claims, losses, damages or legal actions incurred by Portland State University Library and arising from the content or dissemination of the content; and

(iv) In the event of a decision to discontinue the hosting arrangement, provide the Portland State University Library with 6 months prior written notice of its intention to do so.

(v) If no new content or issues are produced for three consecutive years, the journal will be considered to have ceased publication. The Digital Initiatives Unit will contact the publishing editors or departments and confirm that the journal is no longer being published and appropriate notices will be added to the journal information page.

Signature

(Individual authorized to sign on

The behalf of Publisher)

Name (please print)
Signature

(Individual authorized to sign for

Portland State University Library)
Name (please print) 
Address

Telephone number and Email address

Date
Address

Telephone number and Email address

Date 


\section{APPENDIX II}

\section{An Abbreviated Overview of the Migration Procedures}

The PSU Library's Digital Initiatives staff was responsible for steps 1-4, and the Library Technology team completed steps 5-6.

1. In Digital Commons, export a spreadsheet from the collection where we will be uploading the files and metadata. (Necessary for the conversion script and metadata mapping.)

2. Use the established export process and generate the XML files from OJS for each issue

3. Download all attachments related to the articles. Use one folder for each issue / XML file. The location where this is stored will look like this:
a. Issue-1.xml
b. issue-1/
c. Issue 2.xml
d. issue-2/
e. $\quad \ldots$

4. Note the mapping between XML file, article title, and PDF filename. Use a CSV file, since this is simple to edit and parse. Format: "issue","article_title","filename". The filename column can be multi-value. If there are multiple files for an article, separate the names with semicolons.

a. "Issue","article_title","filename"

b. "21","Connecting Information Literacy and Social Justice: Why and How","05_Saunders_PRINT.pdf"

c. "21","Book Review: Emerging Strategies for Supporting Student 
Learning","14_Newhouse_PRINT.pdf"

d. "21","Title with multiple attachments","007_Bond.pdf;JamesBond.pdf"

5. Run the conversion process on each XML file. This will generate a CSV file and a folder full of attachments on the local service.

6. Convert the CSV files to XLS and upload them to Digital Commons. DC should retrieve the attachments referenced in the spreadsheet from the server during import. 


\section{Figure 1}

\section{Having Something to Say}

Christopher V. Hollister, University at Buffalo

Subjects

editorial; journal; information literacy

Document Type

Editorial

DOI

10.15760/comminfolit.2007.1.1.1

Downloads prior to this publication

3332

Persistent Identifier

http://archives.pdx.edu/ds/psu/22485

Recommended Citation

Hollister, C. V. (2007). Having Something to Say. Communications in Information Literacy, 1 (1), 1-2. https://doi.org/10.15760/comminfolit.2007.1.1.1

Figure 1. Example of download counts.
Download

67 DOWNLOADS

Since November 13, 2017

* plumX metrics

d INCLUDED IN

Information Literacy

Commons

SHARE

Altmetric 0 